\title{
The Role of Russian Political Leadership in Foreign Decision-Making Process: Putin and Medvedev (Case Study)
}

\author{
Hussein Mezher Khalaf, Husham Ezzulddin Majeed \\ University of Baghdad, Baghdad, Iraq
}

\begin{abstract}
After Putin took office in April 2000, he adopted a strategy aimed at strengthening central state authority, tightening its grip on economic and political institutions and strengthening its strategic capabilities. He sought to strengthen the Russian state at the international level, restore Russia's status among world powers, and reduce US hegemony over the international order. He began from the inside through the rebuilding of the Russian state and the building of the internal economy, giving attention to the foreign policy through the establishment of friendly relations with the countries of the Central Asian region, as well as the military and diplomatic relations and the increase of Russian military bases in the Central Asian Republics. During Putin's second term in office, Russian foreign relations became more realistic, when Russia's foreign policy goals were announced in an attempt by the political leadership to restore Russia's global role again. In 2008, Medvedev became the prime minister but this new reality did not cancel the influential role of the political leadership (Putin and Medvedev) in foreign policy; although the superficial changes in the general framework of foreign policy, the main course of foreign policy has been steady according to the orientations of the political leadership. The research will highlight the role of Russian political leadership in foreign decision-making, and answer the following questions: Does the Russian political leadership have an active role in foreign decision-making? Who gave these broad powers to the Russian political leadership? And how did Putin and Medvedev use these powers?
\end{abstract}

Keywords: orientations, leadership, Russian, foreign, goals

A basic problem for any analysis of the state is to distinguish between state and regime. This stumbling block is especially tricky in transitional systems where there is no tradition of constitutionalism and constitutional development that enables one to distinguish among state, regime, and government: the locus of power, the rules and limitations governing its use, and particular constellations of political actors using power. However, the fact that state and regime are hard to separate and therefore have to be analyzed together for much of the time does not mean that the two should be treated as identical. This has been a significant problem in most analysis of the Russian state. In particular, emergent regime characteristics have been labelled as characteristics of the state and signs of incipient regime stabilization have, no matter how temporary, been taken as signs that the state and state power (roughly an aggregate of its capacity, organizational integrity, and autonomy) are developing a particular form (Robinson, 2008, p. 3).

Corresponding author: Hussein Mezher Khalaf, Ph.D., Faculty of Political Science, College of Political Science, University of Baghdad, Baghdad, Iraq; research fields: international studies and US foreign policy.

Husham Ezzulddin Majeed, Ph.D., Faculty of Political Science, College of Political Science, University of Baghdad, Baghdad, Iraq; research field: political systems. 
Jeffrey Mankoff, a noted Russian foreign policy scholar and author of Russian Foreign Policy says:

The Return of Great Power Politics contends that the term "Velikaya Derzhava" was used by Vladimir Putin in his early first term in office and first was used by him in his drafting of the "Foreign Policy Concept" and the "National Security Concept" in 2000.

Russian foreign policy therefore ultimately concentrates on creating an international relations system based on sovereign nation states as the guardians of the global order, free to pursue their own national interests while maintaining a larger "balance of power". Russia's leaders never ceased viewing themselves as one of these "great powers". Beginning with former Yeltsin's foreign minister Yevgeny Primakov, Russian diplomats and foreign policy makers have repeatedly emphasized that Russia must have an independent foreign policy economically and militarily, and not simply function as "an appendage of the West or a supplier of natural resources to the world market" (Mankoff, 2009, p. 12).

Thus, since 2000 until today, the Russian political leadership (Putin and Medvedev) plays a key role in shaping and defining the essential lines of Russian foreign policy.

\section{First: The Nature of Russian Political System After 1991}

After the disintegration of the Soviet Union, there has obviously and undeniably been some shift in how power is divided between institutions and elites in Russia, and hence a change in the rules of the political game. Certainly, some of the characteristics of the regime have changed: "Monocentric" power has replaced multiple, overlapping, and competing centers of power and influence at the apex of the political system. These changes have variously been labelled moves to authoritarianism, autocracy, or some form of hybrid regime such as "guided" or "managed" democracy, or "competitive authoritarianism" (Robinson, 2008, p. 3).

A presidential system emerged in the last Soviet years to compensate for the decline of the Communist Party, and later the presidential option looked increasingly attractive to overcome the crisis of reform in Russia. Yeltsin executive authority became relatively independent from the legislature, a trend given normative form by the 1993 constitution. Many functions of the old legislature, including some of its committees and commissions, were incorporated into the presidential system, providing yet another massive impetus to the inflation of the presidential apparatus (Huskey, 1999).

The political system formalized by the 1993 constitution reflected numerous conjunctural factors. A constitution, ideally, reflects a popular consensus around certain principles and values, whereas this constitution contained elements that reflected only the concerns of a particular time and the interests of a particular group. Vitaly Tret'yakov (Виталий Третьяков), the trenchant editor of Nezavisimaya Gazeta (Независимой газете), argued that "It is a constitution for presidents in general and for president Yeltsin in particular". noted that "When the president personally formulates foreign and domestic policy, one can say that the monarchical principle outweighs the democratic principle in the constitution"2.

The 1993 constitution gave the presidency extensive powers in naming governments, introducing legislation, and making policy. The powers of the presidency are based on a combination of appointment powers and policy prerogatives. The president nominates the prime minister and can chair cabinet meetings, proposes to the State Duma and the director of the Central Bank, nominates the Federation Council members of

\footnotetext{
1 Nezavisimaya Gazeta, November 9, 1993, p. 1.

2 Segodnya, November 13, 1993, p. 2.
} 
the Constitutional, Supreme and Supreme Arbitration Courts, and also nominates the Procurator General. The president is also head of the Security Council, confirms Russia's military and foreign policy doctrines, appoints the commander-in-chief of the Armed Forces, and "exercises leadership of the foreign policy of the Russian Federation" (Article 86).

The presidential features of the constitution attracted much criticism. Zor'kin argued that the leading role of the Communist Party had been replaced by the one-man rule of the president, while Rumyantsev argued that the constitution gave legal form to the seizure of power". For Victor Ilyukhin, this was a "constitution for the fascist future", while E. Volodin saw it as inaugurating "the banana republic of Russia"4.

For that, we can say that the 1993 constitution established the foundations of the new polity, but the structure remained to be built (Vile, 1967).

Putin declared early in his first presidential term that he was in favor of changing the constitution to further strengthen the president's power. He also advocated an extension of the presidential term to seven years on his first day in office as acting president (EU-Russia Centre, 2011, p. 16).

As we have seen, the constitution endows the president with control over foreign and security policy as well as the main direction of domestic policy, and it is this article that provides the juridical basis for presidential rule.

Finally we can say, at present Russia is considered to have a "super-presidential" system, although the degree to which there is a genuine separation of powers is sometimes under-rated. The problem is not so much that the constitution lacks a separation of powers, but that it is unbalanced deliberately (Sakwa, 2008, p. 82).

\section{Second: Foreign Decision-Making in the Russian Constitution of 1993}

The collapse of the Soviet Union created an entirely new situation. The Russian political elites were not only forced to develop a new "Russian" foreign policy but also to create new institutions to carry out that policy. This process has not proven easy. Russia has found it difficult to pursue a clear and consistent foreign policy (Larrabee \& Karasik, 1997, p. 1).

Also, there was a big problem, problem of distribution of powers with regard to the foreign decision-making, and who has the greatest influence in foreign policy making (President or Duma?).

This problem has been settled by the adopted Constitution of 1993, which confirmed the president's pre-eminent role. Article 80.3 baldly states that the president "determines the basic guidelines of the state's domestic and foreign policy"; Article 80.4 stipulates that he or she "represents the Russian Federation within the country and in international relations"; and Article 86 specifies that the president "exercises leadership of the foreign policy of the Russian Federation" (Article 86a), conducts negotiations, signs international treaties (Article 86b) and instruments of ratification (Article 86c), and accepts letters of diplomatic accreditation (Article 86d). The president decides membership of the Security Council, chairs its sessions, and is the final arbiter of Russia's military doctrine. The president, in consultation with parliament, nominates ambassadors, and has the right to appoint and dismiss members of the government, including those responsible for foreign policy. The government's powers over foreign policy are limited, authorized only to implement measures for "the realization of the foreign policy of the Russian Federation" (Article 114.1e). In other words, it is intended to do little more than to implement policies coming from the presidency. The work of the MFA (Ministry of

\footnotetext{
${ }^{3}$ Nezavisimaya Gazeta, December 4, 1993, p. 2.

${ }^{4}$ Stolitsa, No. 50 (160), December 1993, p. 4.
} 
Foreign Affairs) in the new conditions was formulated by a presidential statute of 14 March, 1995, subordinating it to the president but delegating to it "the development of the general strategy for Russian foreign policy",

The Constitution referred also to the powers of the State Duma with regard to foreign policy, so the State Duma's functions are restricted to approving or rejecting international treaties (Article 106d), while the Federation Council authorizes the use of Russian troops abroad (Article 102.1d). Both issues could prove controversial. Above all, the committee system ensures that foreign policy issues remain firmly within the purview of deputies (Obolenski, 1990, pp. 7-80; 1995, pp. 12-27).

In practice, between 1992 and 1996, there were indications that Yeltsin made important foreign policy decisions with little or no consultation with other officials of his administration or with the legislative branch ${ }^{6}$, and this means a violation of the powers of the president as stipulated in the constitution.

In the same context, when Putin came to power, the control over foreign policy in the hands of one leader has become true in post-Soviet Russia. No single person in the six decades since the death of Stalin has been so intimately identified with power and policy in Russia. Such is his domination that he has engendered his own "ism". Putinism has emerged as a hybrid of centralized political power, economic rent-seeking, social materialism, conservative morality, and an assertive international posture (Brookings Institution, 2016).

Obviously, under Putin's rule, the system was manipulated to promote the party in power. The right to elect regional governors was removed and the Duma became little more than a rubber stamp for Kremlin policies ${ }^{7}$.

Wherefore, the Russian foreign policy called "presidential" but neither the president nor anyone else has the bureaucratic possibilities of systematically shaping and directing it (Karaganov, December 25, 1994-January 1, 1995, p. 7).

\section{Third: Foreign Decision-Making Between Putin and Medvedev}

When Putin came to power in 1999, he has devoted considerable attention to forging a new and strong direction for Russian foreign policy, trying to regain the status of the former Soviet Union in the Cold War, with some fundamental changes to match the new situation to enable it to realize its ambitions in an age of globalization and freedom. Therefore, the Russian Federation adopted in its foreign policy several departments depending on the stages of their growth and the extent of political and economic stability. In all these circles, the ultimate objective was to achieve long-term security strategy (al-Asfahani, 2001). Thus, the foreign policy has become more pragmatic and coherent in Putin's era (Zakharov, 2007).

There is no doubt that the "Foreign Policy Conception of the Russian Federation (2000)"8 is an excellent foundation to understand Putin's foreign tendencies. As a fundamental, "traditional" foreign policy document, it is in essence an objective document that without excessively propagandistic language lays out a basic framework and architecture of the Putin regime.

This document contained some fundamental concepts of the Russian foreign policy ${ }^{9}$ :

\footnotetext{
${ }^{5}$ Rossiiskaya Gazeta, March 31, 1995, p. 5.

${ }^{6}$ See: http://countrystudies.us/russia/78.htm.

${ }^{7}$ Lilia Shevtsova speaking the ALDE hearing in the European Parliament on February 9, 2011.

${ }^{8}$ For more information about the document, see: http://en.kremlin.ru/supplement/4116.

9 The foreign policy concept of the Russian Federation (approved by the President of the Russian Federation V. Putin on June 28, 2000), pp. 1-2.
} 
(1) To ensure reliable security of the country, to preserve and strengthen its sovereignty and territorial integrity, to achieve firm and prestigious positions in the world community, most fully consistent with the interests of the Russian Federation as a great power, as one of the most influential centers of the modem world, and which are necessary for the growth of its political, economic, intellectual, and spiritual potential;

(2) To influence general world processes with the aim of forming a stable, just, ad democratic world order, built on generally recognized norms of international law, including, first of all, the goals and principles in the U.N. Charter, on equitable and partnership relations among states;

(3) To create favorable external conditions for steady development of Russia, for improving its economy, enhancing the standards of living of the population, successfully carrying out democratic transformations, strengthening the basis of the constitutional system and observing individual rights and freedoms;

(4) To form a good-neighbor belt along the perimeter of Russia's borders, to promote elimination of the existing and prevent the emergence of potential hotbeds of tension and conflicts in regions adjacent to the Russian Federation;

(5) To seek concord and coinciding interests with foreign countries and interstate associations in the process of resolving the tasks that are determined by the national priorities of Russia, and on this basis, to build a system of partnership and allied relations that improve the conditions and parameters of international cooperation;

(6) To uphold in every possible way the rights and interests of Russian citizens and fellow countrymen abroad;

(7) To promote a positive perception of the Russian Federation in the world, to popularize the Russian language and culture of the peoples of Russia in foreign states.

On this basis, during his presidency (2000-2008), Putin made every effort to recover Russia's super power status and international respect. He did not hesitate to use the privileged position of Russia-main energy supplier to Europe, a permanent member of the Security Council of the United Nations, a continuing influence over the post-Soviet space - to achieve his ambitious goal (Rousseau, 2015, p. 3).

Following the inauguration of Russian President Dmitry Medvedev in May 2008, the Russian political scene was characterized by a new structure: The country was governed by a bicephalous system (which reflected the two-headed eagle of the national flag). Medvedev became President and Vladimir Putin assumed the position of Prime Minister. In this ostensibly tandem structure, the Chief Executive was subordinated to the President as was the case even before Russia first emerged as an independent country in the wake of the collapse of the Soviet Union (Rousseau, 2015, p. 3).

Just like Putin in 2000, President Medvedev launched a new Foreign Policy Concept in 2008, which presents priorities in terms of aims and means, and enumerated the following basic objectives (quotes edited) (Oldberg, 2010, pp. 2-3):

(1) Safeguarding the security of the country, maintaining and strengthening its sovereignty and territorial integrity, its strong and authoritative positions as one of the influential centers in the world;

(2) Creating good external conditions for Russia's modernization for raising the population's living standard, consolidating society, strengthening the foundations of the constitutional system, rule of law state and democratic institutions, realizing human rights and freedoms, and thus secure the competitiveness of the country in a globalizing world; 
(3) Influencing global processes in order to establish a just and democratic world order based on collective principles and the supremacy of international law, in particular the principles of the UN Charter;

(4) Creation of good-neighborly relations with adjacent states and assistance in eliminating existing and preventing the emergence of new hotbeds of tension and conflicts in the adjoining regions of the Russian Federation and other parts of the world;

(5) Seeking consensus and coinciding positions with other states and international organizations in the process of solving tasks defined by Russia's national interests;

(6) Comprehensive defense of the rights and interests of Russian citizens and compatriots living abroad;

(7) Contributing to an objective perception of Russia in the world as a democratic state with a socially oriented market economy and an independent foreign policy;

(8) Promoting and popularizing the Russian language and the cultures of the peoples of Russia abroad.

Although there are rather superficial differences in the foreign policy concepts between Putin and Medvedev but we believe that the basic principles are largely fixed.

Here, one must posit the question of whether or not the vision of President Dmitry Medvedev and his personal approach in foreign policy are contrasted to Putin.

Many indications refer that Putin is more powerful than Medvedev, especially in information recently reaffirmed by the Wikileaks "scandal", that indeed Putin is the real person in charge and essential "Batman", while Medvedev is the second fiddle "Robin", and not really controlling things, especially in the field of foreign policy which is according to the Russian constitution under the auspices of the President and not the Prime Minister (Ioffe, 2010); and Putin often declared that it is the president, not the premier (when Medvedev was prime minister), who determines Russia's foreign policy, and the main players responsible for the formulation and implementation of Russian foreign policy during Medvedev's term were Putin appointees. These included influential presidential aide Sergei Prikhodko, Foreign Minister Sergey Lavrov, Foreign Intelligence Chief Mikhail Fradkov, and others (Kozhanov, 2012).

Despite this, Medvedev was trying to change Russian external behavior, through embracing Washington's desire to "press the reset button" on its relations with Russia, altering policy towards Iran (he cancelled the planned sale of S-300 air-defense missile systems and approved United Nations sanctions in June 2010), attending NATO's Lisbon summit in 2010, and authorizing Russia's abstention from a UN Security Council resolution on Libya which paved the way for NATO to launch its 2011 mission there. However, he also sent Russian troops into Georgia in August 2008 in support of the breakaway province of South Ossetia, and later granted recognition to Abkhazia and South Ossetia as independent states (International Institute for Strategic Studies, 2012).

But all these steps have not changed the reality of Russian foreign policy, which is a reflection of the vision and thought of one man (Putin). For that, if anyone analyzes Russia's activity in the period from spring 2008 to autumn 2011, he needs to remember that its foreign policy was not the sole responsibility of Medvedev.

\section{Fourth: The Current Russian Foreign Policy}

In addition to the above, we see clearly that the current Russian foreign policy is heavily influenced by neo-nationalist rhetoric and sentiment. Furthermore, this rhetoric is central to the strategy of the Putin/Medvedev regime in having Russia assumed its traditional role as a "Velikaya Derzhava" or "great power", an idea that hearkens back through Soviet and even to Tsarist times. This rhetoric is used in the 
speeches and proclamations of the regime, especially in the key events during the tenure of Putin. A key tactic of the Putin/Medvedev regime has been to purposefully and knowingly use neo-nationalist rhetoric and symbolism and manipulate the key traditional symbolism of Russian Soviet and Tsarist history. This has resulted in a neo-nationalist renaissance of Soviet symbols of the traditional institutions of Russian central state authority, namely the military, a strong almost paternalistic government headed by Putin, and also the Russian Orthodox Church. This rhetoric takes the form of the protection of Russian interests and citizens in Russia's sphere of hegemony, i.e. its inner and near abroad and its self-proclaimed "sphere of privileged interests" of which Chechnya, Ukraine, and Georgia are a key part (Isajiw, 2016, pp. 1-2).

In the same context, in a seminal article entitled "Russia Reborn: Reimagining Moscow's Foreign Policy", Dmitri Trenin, whom Edward Lucas refers to as a "well connected" Russian foreign policy analyst, looks at what he considers to be Putin's mostly failed nationalistic re-casting of Russia as an independent great power. Most of these failures and flaws are due to the regime of Putin/Medvedev's inability to diversify the economy away from reliance on energy resources and a clinging to the ideological and political relics of the Soviet past. According to Trenin,

Russia's leaders have chosen growth without development, capitalism without democracy, and great power policies without international appeal... these cannot hold forever. Russia will fail to achieve its principal foreign policy objectives, it will fall further behind in a world with open borders and instant communications leading to dangers not only to its status but also its existence. Russian foreign policy needs more than a reset: it requires a new strategy and policy instruments. (Trenin, Malashenko, \& Lieven, 2004)

However, we can observe today that the present-day regime of Russian President Dmitri Medvedev and former Prime Minister Vladimir Putin is one that is caught at a crossroads of identity. Modern-day Russia as a whole is a nation that is struggling to find its place in an ever globalizing world, where national borders and even the notion of the Westphalian nation state arguably mean less in terms of global prestige and power, and where economic strength and open liberal markets are the hallmarks of success and influence in the post-Cold War and post-Soviet global international order. Thus, simply speaking, as contended by Dmitri Trenin, the fundamental twin questions on the national and indeed international agenda of the Putin and Medvedev regime at the beginning of the 21st century are the key questions of: What is Russia? Who is Russian? As Trenin contends, the problem of Russia is partially a problem of space and borders: "a problem which is inseparably linked to and compounded by the problem of identity" (Trenin, 2002, p. 26).

\section{Conclusions}

It is clear that the Russian Constitution of 1993 gave the presidency a broad role in the foreign decision-making process, and there is no doubt that when Putin came to power, it has strengthened the presidency role in the field of foreign policy. The absolute power made Putin able to develop foreign strategies and make decisions according to his own vision; for that, when Putin came to power, there has been a shift to a new approach, an approach which emphasizes the new role of Russia in the international system. Notably, when Medvedev came to power, there was no shift in the external orientations, and the principles of foreign policy developed by Putin in 2000 remained the same with a slight change in terminology and general concepts.

Quite clearly, the foreign policy of Putin/Medvedev regime is heavily influenced by neo-nationalist rhetoric and sentiment. Furthermore, this rhetorical is central to the strategy of the Putin/Medvedev statute in having Russia assumed its traditional role as a "great power". 
We conclude that the Russian political leadership after 1999 was able to dominate the planning and implementation of foreign policy significantly.

\section{References}

al-Asfahani, N. (2001). The future of Russian-Iranian cooperation in light of recent convergence. International Policy, Vol. 36, No. 144. Cairo: Center for Political and Strategic Studies.

Brookings Institution. (2016). The domestic context of Russian foreign policy. Retrieved from https://www.brookings.edu/wpcontent/uploads/2016/07/Chapter-One-12.pdf

EU-Russia Centre. (2011). The electoral system of the Russian Federation. The Eu-Russia Centre Review, Issue Seventeen. Retrieved from https://www.files.ethz.ch/isn/143427/Review17.pdf

Huskey, E. (1999). Presidential power in Russia. Armonk, NY: M. E. Sharpe.

International Institute for Strategic Studies. (2012). Grading Medvedev's foreign policy. Retrieved from http://www.realclear world.com/articles/2012/05/15/grading_medvedevs_foreign_policy_100052.html

Ioffe, J. (2010). Holy Wikileaks, Batman! In Russia, Julian Assange can't tell them anything they don't know. Retrieved from http://www.foreignpolicy.com/articles/2010/11/29/holy_wikileaks_batman

Isajiw, C. P. (2016). Neo-nationalism in the foreign policy of the Putin/Medvedev regime. Retrieved from http://www.e-ir.info/ 2016/06/22/neo-nationalism-in-the-foreign-policy-of-the-putinmedvedev-regime/

Karaganov, S. (December 25, 1994-January 1, 1995). Rudderless and without sails. Moscow news, No. 66.

Kozhanov, N. (2012). Russian foreign policy after Putin's return. Retrieved from http://www.washingtoninstitute.org/policyanalysis/view/russian-foreign-policy-after-putins-return

Larrabee, F. S., \& Karasik, T. W. (1997). Foreign and security policy decisionmaking under Yeltsin. Washington, D.C.: RAND Corporation.

Mankoff, J. (2009). Russian foreign policy, the return of great power politics. USA: Rowman and Littlefield.

Obolenski, A. V. (1990). The mechanism of inhibition: The human dimension, the law of the Soviet state. No. 1, pp. 7-80.

Obolenski, A. V. (1995). Russian politics in the time of troubles. In A. Saikal and W. Maley (Eds.), Russia in search of its future. Cambridge: Cambridge University Press.

Oldberg, I. K. (2010). Russia's great power ambitions and policy under Putin. Utrikespolitiska Institute, Swedish Institute of International Affairs. Retrieved from https://www.researchgate.net/publication/304734845_Russia's_Great_Power_Ambition s_and_Policy_Under_Putin

President of Russia. (2008). The foreign policy concept of the Russian Federation. Retrieved from http://en.kremlin.ru/supple ment $/ 4116$

Robinson, N. (2008). State, regime and Russian political development. Limerick Papers in Politics and Public Administration, University of Limerick. Retrieved from https://www.ul.ie/ppa/content/files/Robinson_state.pdf

Rousseau, R. (2015). Russian foreign policy under Dmitry Medvedev's presidency (2008-2012). The Center for Strategic Research and Analysis (CESRAN International). Retrieved from http://cesran.org/cesran-papers-8

Sakwa, R. (2008). Russian politics and society (4th ed.). London and New York: Taylor \& Francis e-Library.

Trenin, D. (2002). The end of Eurasia: Russia on the border between geopolitics and globalization. Washington, D.C.: Carnegie Endowment for International Peace.

Trenin, D., Malashenko, A., \& Lieven, A. (2004). Russia's restless frontier: The Chechnya factor in post-Soviet Russia. Washington, D.C.: Carnegie Endowment for International Peace. Retrieved from http://carnegieendowment.org/1970/01/01/ dmitri-trenin-alexey-malashenko-anatole-lieven-russia-s-restless-frontier-chechnya-factor-in-post-soviet-russia-pub-35734

Vile, M. J. C. (1967). Constitutionalism and the separation of powers. Oxford: Clarendon Press.

Zakharov, M. (2007). Who is Boris Yeltsin?-Political scientists, journalists and politicians remember the first president. April 23, Russia. 